\title{
Toksisitas Partisi N-Heksan dan Etil Asetat pada Ekstrak Sargassum sp. terhadap Larva Aedes aegypti Instar III
}

\author{
Alfianisa Permata Sari ${ }^{1 *}$, Ervia Yudiati ${ }^{1,2}$, Sunaryo $^{1}$ \\ ${ }^{1}$ Departemen IImu Kelautan, Fakultas Perikanan dan IImu Kelautan, Universitas Diponegoro \\ ${ }^{2}$ Laboratory of Tropical Marine Biotechnology, Universitas Diponegoro \\ JI. Prof. H. Soedarto S.H, Tembalang, Semarang, Jawa Tengah 50275 Indonesia \\ *Corresponding author, e-mail : alfianisaps1@gmail.com
}

\begin{abstract}
ABSTRAK: Kejadian demam berdarah dengue pada awal 2019 tercatat lebih dari 17.000 kasus demam berdarah dengan angka kematian mencapai 169 jiwa di seluruh Indonesia. Sargassum sp. merupakan jenis rumput laut cokelat berlimpah namun belum dimanffatkan dengan baik. Sargassum sp memiliki beragam aktivitas biologis. Penelitian ini bertujuan untuk mengetahui toksisitas ekstrak rumput laut cokelat Sargassum sp. larva Aedes aegypti instar III. Ekstraksi dilakukan dengan cara maserasi sampel Sargassum sp. dengan pelarut metanol, dilanjutkan partisi dengan pelarut $n$-heksana dan etil asetat serta analisis fitokimia menggunakan kromatografi lapis tipis. Sepuluh ekor larva nyamuk dipaparkan dalam $100 \mathrm{ml}$ aquades dengan beberapa konsentrasi ekstrak (0, 50, 100, 250, 500 dan 1000 ppm), abate sebagai kontrol positif dan DMSO dengan tiga kali ulangan. Aktivitas larvasida ekstrak Sargassum sp. juga ditentukan dengan menghitung nilai $\mathrm{LC}_{50}$ pada jam ke-72. Perubahan morfologi diamati secara mikroskopis. Fraksi n-heksana dan etil asetat Sargassum sp. memiliki nilai LC $_{50}$ berturut-turut sebesar 3129.15 ppm dan 996.28 ppm. Larva yang dipaparkan dengan ekstrak etil asetat Sargassum sp. memiliki kerusakan morfologi pada bagian kepala, siphon, saluran pencernaan, papila anal serta warna tubuh menjadi lebih gelap. Keseluruhan fraksi n-heksana dan etil asetat Sargassum sp. mengandung senyawa golongan fenolat dan terpenoid. Berdasarkan hasil tersebut, fraksi etil asetat Sargassum sp. berpotensi sebagai larvasida.
\end{abstract}

Kata Kunci: Aedes aegypti; LC $_{50}-72$; Sargassum sp.

\section{Partition Toxicity of N-Hexane and Ethyl Acetate in Sargassum sp. against Larva Aedes aegypti Instar III}

ABSTRACT: In the early 2019, there has been 17,000 Indonesian people suffered and 169 died from Dengue epidemic. Sargassum sp. in Indonesian waters were plentiful, rich in biological activity and still unexpolitated. This study aimed to determine the 72-h $L C_{50}$ of Sargassum sp. extract to Aedes aegypti instar III larvae. Extraction was done by maseration with methanol, partitioned with nhexane and ethyl acetate, folowed by TLC analysis. Ten larvae were exposed with $100 \mathrm{~mL}$ aqudest in a serial concentration (0; 50;100; 25; 500 dan 1000 ppm), completed with Abate® powder as positive, aquadest as negative control. All treatments were replicated three times. Observation on morphological aberration was done microscopically. $72-h L C_{50}$ of $n$-hexane and ethyl acetate fraction were $3129.15 \mathrm{ppm}$ dan $996.28 \mathrm{ppm}$, respectively. There were larval morphologically damage in head, siphon, digestive tract and papilla anal and dark coloured body. Extract were composed with phenolate and terpeniod coumpoud. It is concluded that Sargassum sp. extract was a good source for larvacide.

Keywords: Aedes aegypti; 72-h LC $C_{50}$; Sargassum sp.

\section{PENDAHULUAN}

Salah satu penyakit menular yang masih menjadi masalah kesehatan masyarakat adalah Demam Berdarah Dengue (DBD). Demam berdarah adalah penyakit yang banyak ditemukan di daerah tropis dan sub-tropis, terutama di kawasan Asia yang menempati urutan pertama jumlah 
penderita DBD setiap tahunnya. Sejak tahun 1968 hingga tahun 2009, World Health Organization (WHO) mencatat negara Indonesia sebagai negara dengan kasus DBD tertinggi di Asia Tenggara (Kementerian Kesehatan RI, 2010). Sementara pada awal 2019 tercatat lebih dari 17.000 kasus demam berdarah dengan angka kematian mencapai 169 jiwa di seluruh Indonesia.

Virus Dengue sebagai penyebab demam berdarah hanya dapat ditularkan melalui nyamuk Aedes aegypti. Selain menularkan virus dengue, $A$. aegypti juga dapat menularkan penyakit demam kuning, filariasis limfatik dan malaria (Valentina et al., 2015). Dalam penyebaran demam berdarah dipengaruhi oleh faktor iklim seperti curah hujan, suhu dan kelembaban. Menurut Suryani (2018), kelangsungan hidup nyamuk akan lebih lama bila tingkat kelembaban tinggi, seperti selama musim hujan.

Indonesia memiliki banyak sumber daya alam hayati di laut. Salah satunya yang banyak dimanfaatkan adalah Sargassum sp.. Sargassum sp. adalah ganggang makro yang berwarna cokelat termasuk dalam kelas phaeophyceae dan ordo fucales. Sargassum sp. termasuk produk alam dari laut yang memiliki kemampuan sebagai antitumor, antioksidan, antibakteri, antijamur, anti inflamasi dan antivirus (Mary et al., 2012). Senyawa yang berperan sebagai antimikroba adalah flavonoid (Ervina et al., 2014), saponin dan terpenoid (Widawati dan Heni, 2013).

Berdasarkan penelitian yang telah dilakukan oleh Yu et al. (2015), ekstrak Sargassum binderi dan Padina australis dari perairan Teluk Kemang, Malaysia mampu membunuh larva A. aegypti dengan LC $_{50}$ berturut-turut yaitu $192,43 \mathrm{mg} / \mathrm{mL}$ dan $340,90 \mathrm{mg} / \mathrm{mL}$. Penelitian larvasida terhadap rumput laut cokelat juga dilakukan oleh Valentina et al. (2015), yang diperoleh hasil bahwa ekstrak Turbinaria conoides memiliki nilai $\mathrm{LC}_{50} 64,27 \mathrm{mg} / \mathrm{mL}$.

Sejauh ini, penanganan preventif terhadap larva nyamuk $A$. aegypti yakni menggunakan Abate $\AA$. Dimana Abate $®$ merupakan larvasida sintetik yang memiliki dampak negatif terhadap lingkungan seperti polusi lingkungan, serangga menjadi resisten dan toleran terhadap pestisida serta keracunan bagi manusia atau hewan sekitarnya (Rochmat et al., 2016). Adanya bahan-bahan alam seperti Sargassum sp. berpotensi sebagai pengganti larvasida kimia sintetik. Berdasarkan hal tersebut maka penelitian ini perlu dilakukan. Tujuan dari penelitian ini yaitu untuk mengetahui tingkat toksisitas Sargassum sp. terhadap larva nyamuk $A$. aegypti.

\section{MATERI DAN METODE}

Materi yang digunakan adalah Sargassum sp. yang digunakan berasal dari Pantai Teluk Awur, Jepara dan larva Aedes aegypti diperoleh dari Balai Penelitian dan Perkembangan Kesehatan, Banjarnegara. Metode penelitian ini menggunakan metode experimental laboratories. Tahapan penelitian terdiri dari ekstraksi, penetasan larva $A$. aegypti, uji toksisitas, pengamatan morfologi dan uji kromatografi lapis tipis.

Pembuatan ekstrak Sargassum sp. mengacu pada Yu et al. (2015). Sargassum sp. yang diperoleh dari laut, dicuci terlebih dahulu. Selanjutnya dipotong kecil-kecil dengan ukuran $\pm 2 \mathrm{~cm}$ dan dihaluskan dengan blender. Sebanyak $150 \mathrm{~g}$ Sargassum sp. direndam dalam $600 \mathrm{~mL}$ metanol selama $3 \times 24$ jam. Hasil maserasi dipekatkan menggunakan rotary evaporator dengan suhu $50^{\circ} \mathrm{C}$ hingga diperoleh ekstrak metanol hingga volume tersisa $\pm 50 \mathrm{~mL}$. Kemudian ekstrak metanol tersebut dipartisi dengan dua pelarut yang berbeda, yakni etil asetat dan n-heksana. Ekstrak ini disebut sebagai fraksi etil asetat dan fraksi n-heksana. Rendemen ekstrak dihitung dengan rumus berikut (Leksono et al., 2018):

$\%$ Rendemen $=\frac{\text { Jumlah berat ekstrak pasta }(\mathrm{g})}{\text { Jumlah berat awal }(\mathrm{g})} \times 100 \%$
Keterangan $:$ Berat ekstrak $=($ Berat vial + ekstrak $)-$ berat vial kosong $(\mathrm{g})$

Penetasan larva A.aegypti dilakukan dengan merendam ovitrap yang berisi telur nyamuk $A$. aegypti dalam nampan yang berisi air galon dan diberi makan pelet. Nampan disimpan pada tempat dengan penerangan secukupnya. Telur $A$. aegypti akan menetas dan menjadi larva instar III setelah 6-7 hari. Larva yang digunakan adalah larva instar III yang aktif bergerak (Rochmat et al., 2016). 
Uji toksisitas ini mengacu pada penelitian Rochmat et al. (2016). Larutan uji toksisitas fraksi n-heksana dan etil asetat dari Sargassum sp. dibuat dengan lima konsentrasi berbeda yakni 50, 100, 250, 500 dan 1000 ppm, kontrol negatif (aquades) dan kontrol positif (abate 100 pm) dengan tiga kali ulangan. Larva nyamuk $A$. aegypti dimasukkan dalam gelas yang berisi aquades sebanyak 10 ekor. Kemudian ditambahkan dengan larutan uji. Pengamatan mortalitas larva dilakukan setiap 24 jam sampai jam ke-72.

Nilai toksisitas $\left(\mathrm{LC}_{50}-72\right)$ ditentukan dengan analisis probit yang memiliki persamaan $\mathrm{Y}=\mathrm{a}+\mathrm{bX}$. Nilai $\mathrm{LC}_{50-72}$ diperoleh dari anti $\log \mathrm{m}$, dimana $\mathrm{m}$ merupakan logaritma konsentrasi pelarut pada $Y=5$, yaitu nilai probit $50 \%$ hewan uji. Nilai $\mathrm{m}$ diperoleh dari rumus berikut (Leuwol et al., 2018):

$$
\begin{gathered}
\mathrm{Y}=\mathrm{a}+\mathrm{bX} \\
\mathrm{bX}=\mathrm{Y}-\mathrm{a} \\
\mathrm{X}=\frac{\mathrm{Y}-\mathrm{a}}{\mathrm{b}}
\end{gathered}
$$

Dimana $X=m$ dan $Y=5$, jadi persamaan regresinya menjadi:

$$
m=\frac{5-a}{b}
$$

Nilai a dan b diperoleh berdasarkan persamaan berikut:

Nilai $\mathrm{LC}_{50}-72$ diperoleh sebagai berikut:

$$
\begin{gathered}
b=\frac{\sum X Y-1 / n\left(\sum X \cdot \sum Y\right)}{\sum X^{2}-1 / n\left(\sum X\right)^{2}} \\
a=1 / n\left(\sum X-b \cdot \sum Y\right)
\end{gathered}
$$

$$
\mathrm{LC}_{50}-72=\text { anti log } \mathrm{m}
$$

Keterangan : $\mathrm{Y}=$ Probit persentase kematian; $\mathrm{X}=$ Logaritma konsentrasi; $\mathrm{m}=$ nilai $\mathrm{LC}_{50}-72 ; \mathrm{n}=$ jumlah perlakuan konsentrasi ekstrak; $a=$ Konstanta; $b=$ Slope/ kemiringan

Morfologi larva $A$. aegypti sebelum dan setelah uji toksisitas diamati menggunakan mikroskop. Uji kromatografi lapis tipis mengacu pada Alen et al. (2017). Plat KLT yang digunakan berukuran $1 \times 6 \mathrm{~cm}$. Ujung plat masing-masing diberi garis pembatas ukuran $0,5 \mathrm{~cm}$, sehingga jarak tempuhnya adalah $5 \mathrm{~cm}$. Plat dimasukkan dalam bejana pengembang yang berisi eluen. Campuran eluen yang digunakan untuk fraksi n-heksana yaitu, n-heksana dan etil asetat dengan perbandingan 7:3 (v/v). Sedangkan campuran eluen untuk fraksi etil asetat yaitu, $\mathrm{n}$-heksana dan etil asetat dengan perbandingan 3:1 (v/v). Setelah itu divisualisasi dengan sinar UV $366 \mathrm{~nm}$ dan vanilin $6 \%$.

\section{HASIL DAN PEMBAHASAN}

Ekstraksi Sargassum sp. menggunakan cara maserasi dengan pelarut metanol. Metode maserasi dipilih karena mampu mengekstraksi senyawa dengan baik melalui perendaman tanpa pemanasan sehingga menghindari kerusakan pada senyawa yang bersifat termolabil (Mukhriani, 2014). Metanol memiliki sifat universal sebagai pelarut, yakni mampu melarutkan analit yang memiliki sifat polar, semi polar dan non polar yang terkandung dalam Sargassum sp.. Metanol dapat menarik analit berupa alkaloid, steroid, saponin dan flavonoid yang berasal dari tanaman (Agustina et al., 2018). Sementara untuk partisi menggunakan pelarut etil asetat dan $n$-heksana dimana pelarut etil asetat bersifat semi polar sedangkan n-heksana memiliki sifat non polar (Susanti et al., 2012).

Hasil ekstraksi tersebut menunjukkan bahwa fraksi etil asetat Sargassum sp. memiliki berat ekstrak lebih banyak dibanding fraksi n-heksana yakni $0,32 \%$ dan $0,28 \%$. Susanty dan Fairus (2016) menjelaskan bahwa perbedaan hasil ekstrak dapat dipengaruhi oleh jenis pelarut, ukuran partikel sampel serta lama waktu ekstraksi. Hasil ekstrak Sargassum sp. pelarut etil asetat yang lebih besar 
daripada pelarut n-heksana karena perbedaan polaritas antara kedua pelarut tersebut, yakni pelarut nheksana memiliki polaritas lebih rendah. Sehingga menunjukkan bahwa senyawa dalam ekstrak Sargassum sp. memiliki kepolaran yang mendekati etil asetat, karena perolehan senyawa didasarkan pada kesamaan kepolaran dengan pelarut. Senyawa yang memiliki sifat seperti pelarut tersebut maka akan larut dalam pelarut yang sifatnya sama.

Rendemen yang diperoleh dalam penelitian ini relatif kecil. Hal ini menunjukkan bahwa kandungan metabolit sekunder dalam sampel relatif sedikit. Faktor lingkungan tempat tinggal Sargassum sp. merupakan perairan yang tenang dengan arus dan gelombang yang relatif kecil diduga menjadi penyebabnya, karena tidak banyak metabolit sekunder yang dihasilkan untuk mempertahankan hidupnya. Uji toksisitas merupakan suatu uji yang dilakukan untuk mengetahui nilai $\mathrm{LC}_{50}-72$ mutu bahan ekstrak. Parameter uji toksisitas ini adalah jumlah mortalitas larva $A$. aegypti instar III dari total hewan uji. Pada pengujian ini digunakan kontrol positif (Abate® 100 ppm) dan kontrol negatif (aquades).

Berdasarkan hasil perhitungan, terjadi peningkatan mortalitas tiap perlakuan pada ekstrak nheksana maupun etil asetat seiring dengan peningkatan konsentrasi ekstrak Sargassum sp.. Hal ini sesuai dengan penelitian Rahmayanti et al. (2016), bahwa semakin tinggi konsentrasi dan semakin lama waktu paparan maka semakin tinggi juga kematian larva. Kemampuan larvasida dalam membunuh larva sangat bergantung pada bentuk bahan, cara masuk bahan ke dalam tubuh, konsentrasi dan jumlah (dosis) larvasida. Noshirma dan Ruben (2016) juga menjelaskan bahwa ekstrak dikategorikan aktif jika ekstrak tersebut menyebabkan kematian $50 \%$ hewan uji selama waktu tertentu. Aktivitas toksititas suatu ekstrak ditentukan dengan melihat nilai LC $_{50}$. Pada penelitian ini ekstrak Sargassum sp. mampu membunuh 50\% hewan uji. Namun dilihat dari nilai $\mathrm{LC}_{50}$ tergolong tinggi, dimana $\mathrm{LC}_{50}$ fraksi n-heksana Sargassum sp. adalah $3129,15 \mathrm{ppm}$ sedangkan fraksi etil asetat Sargassum sp. adalah 996,28 ppm. Fraksi etil asetat bersifat toksik karena nilai $\mathrm{LC}_{50}-72<1000 \mathrm{ppm}$. Sementara fraksi n-heksana bersifat tidak toksik karena nilai $\mathrm{LC}_{50}{ }^{-}$ $72>1000$ ppm. Tingginya nilai $\mathrm{LC}_{50}$ diduga karena kandungan metabolit sekunder yang terdapat dalam sampel relatif rendah sehingga metabolit sekuder yang larut dalam proses maserasi juga rendah. Hal inilah yang mempengaruhi rendahnya aktivitas larvasida. Faktor yang mempengaruhi rendahnya metabolit sekunder adalah kondisi habitat sampel. Perairan yang tenang dengan arus dan gelombang yang rendah maka produksi metabolit sekundernya juga rendah. Sementara perairan yang memiliki arus dan gelombang yang tinggi, produksi metabolit sekundernya juga akan tinggi. Karena organisme tersebut membutuhkan metabolit sekunder untuk mempertahankan hidupnya.

Tabel 1. Nilai LC $_{50}$ pada Uji Toksisitas Fraksi n-heksana dan etil asetat Sargassum sp. dengan waktu Pemaparan 72 Jam

\begin{tabular}{|c|c|c|c|c|c|c|c|}
\hline \multirow{2}{*}{ Ekstrak } & \multirow{2}{*}{$\begin{array}{l}\text { Konsentrasi } \\
\text { (ppm) }\end{array}$} & \multicolumn{3}{|c|}{ Nilai Mortalitas Larva } & \multirow{2}{*}{ Rerata } & \multirow{2}{*}{$\begin{array}{c}\text { Persentase } \\
\text { Mortalitas (\%) }\end{array}$} & \multirow{2}{*}{$\begin{array}{c}\mathrm{LC}_{50}-72 \\
(\mathrm{ppm})\end{array}$} \\
\hline & & Ulangan 1 & Ulangan 2 & Ulangan 3 & & & \\
\hline \multirow{7}{*}{$\begin{array}{c}\mathrm{N}- \\
\text { heksana }\end{array}$} & 0 & 0 & 0 & 0 & 0 & 0 & \multirow{7}{*}{3129,15} \\
\hline & 50 & 2 & 2 & 3 & 2,33 & 23,33 & \\
\hline & 100 & 3 & 2 & 4 & 3 & 30 & \\
\hline & 250 & 3 & 4 & 3 & 3,33 & 33,33 & \\
\hline & 500 & 4 & 4 & 3 & 3,67 & 36,67 & \\
\hline & 1000 & 4 & 5 & 4 & 4,33 & 43,33 & \\
\hline & Abate $®$ & 10 & 10 & 10 & 10 & 100 & \\
\hline \multirow{7}{*}{ Etil asetat } & 0 & 0 & 0 & 0 & 0 & 0 & \multirow{7}{*}{996,28} \\
\hline & 50 & 2 & 2 & 0 & 1,33 & 13,33 & \\
\hline & 100 & 1 & 1 & 2 & 1,33 & 13,33 & \\
\hline & 250 & 1 & 2 & 2 & 1,67 & 16,67 & \\
\hline & 500 & 1 & 2 & 2 & 1,67 & 16,67 & \\
\hline & 1000 & 5 & 5 & 8 & 6 & 60 & \\
\hline & Abate $®$ & 10 & 10 & 10 & 10 & 100 & \\
\hline
\end{tabular}


Analisis Kromatografi Lapis Tipis (KLT) merupakan penentuan golongan senyawa aktif yang terdapat dalam ekstrak berdasarkan warna dan nilai faktor retardasi (Rf) (Fajriaty et al., 2017). KLT menggunakan prinsip adsorbsi dan partisi yang ditentukan oleh fase diam (adsorben) dan fase gerak (eluen) (Lestari et al., 2014). Komponen kimia dari ekstrak bergerak naik mengikuti eluen dan akan diserap oleh adsorben. Adsorben memiliki daya serap yang berbeda terhadap komponen-komponen kimia sehingga komponen kimia dapat bergerak dengan jarak yang berbeda berdasarkan tingkat kepolarannya. Hal inilah yang menyebabkan terjadinya pemisahan komponenkomponen kimia di dalam ekstrak (Alen et al., 2017). Uji KLT pada ekstrak Sargassum sp. dilakukan dengan menotolkannya pada plat KLT yang dielusikan dengan eluen untuk fraksi nheksana yaitu, n-heksana dan etil asetat dengan perbandingan 7:3 (v/v). Sedangkan untuk fraksi etil asetat yaitu, n-heksana dan etil asetat dengan perbandingan 3:1 (v/v). Analisa hasil KLT dilakukan pada masing-masing fraksi dengan visualisasi sinar UV dan vanilin $6 \%$.

Deteksi senyawa menggunakan sinar UV merupakan deteksi senyawa yang paling universal, karena hampir semua senyawa dapat menyerap sinar tampak atau sinar UV dengan berfluoresensi pada panjang gelombang $366 \mathrm{~nm}$ (Wulandari, 2011). Senyawa yang dapat berinteraksi dengan sinar UV yakni golongan senyawa fenolat yang memiliki gugus aromatik

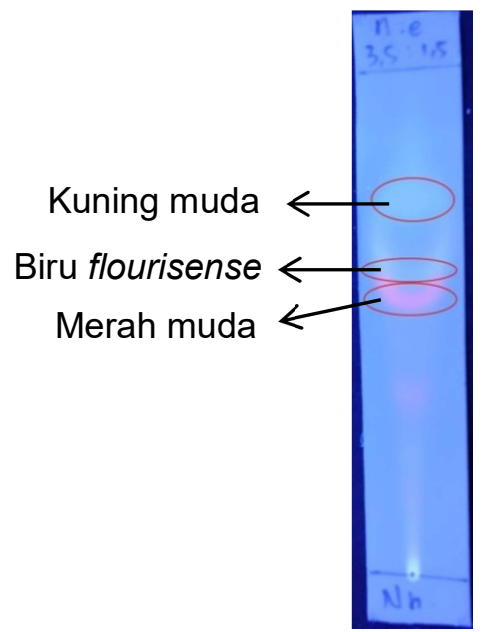

(a)

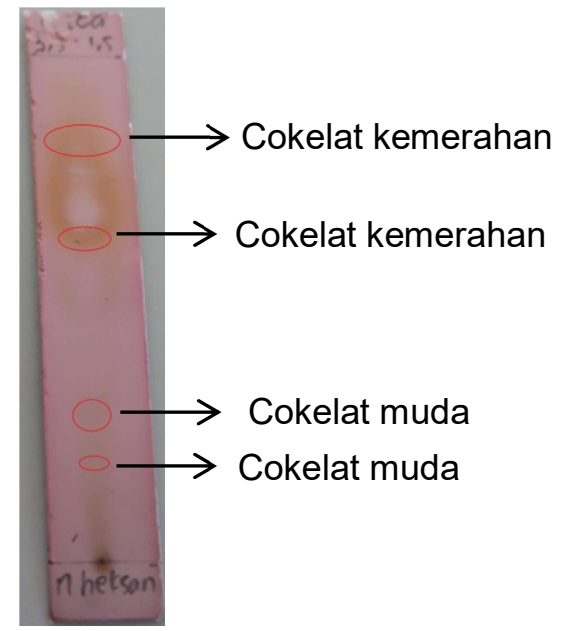

(b)

Gambar 1. Profil Ekstrak Sargassum sp. Fraksi n-heksana Visualisasi (a) Sinar UV 366 nm (b) Vanilin 6\% (Perbandingan Eluen n-heksana:Etil Asetat 7:3)

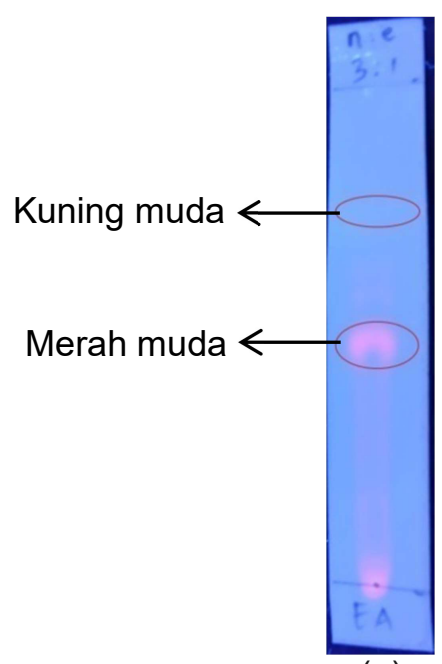

(a)

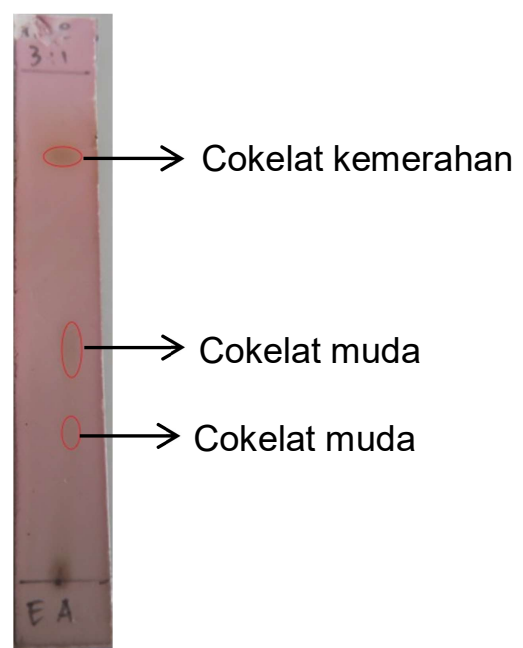

(b)

Gambar 2. Profil Ekstrak Sargassum sp. Fraksi Etil Asetat Visualisasi (a) Sinar UV 366 nm (b) Vanilin 6\% (Perbandingan Eluen n-heksana:Etil Asetat 3:1) 
karena gugus aromatik dapat menyerap sinar UV dengan panjang gelombang $366 \mathrm{~nm}$ (Adinata et al., 2013). Khadijah et al. (2017) menjelaskan bahwa senyawa fenolat memiliki gugus aromatik dengan satu atau lebih gugus hidroksi $(-\mathrm{OH})$ dan gugus-gugus lain penyertanya. Senyawa turunan dari fenolat yang jumlahnya sangat melimpah adalah flavonoid. Gugus keton juga terdapat dalam senyawa flavonoid, karena teridentifikasi terdapat serapan gugus karbonil pada spektrum inframerah, tetapi tidak bereaksi dengan reagen Tollens dan Fehling (Arum et al., 2012). Kelompok senyawa lain yang memiliki gugus keton yaitu saponin.

Pereaksi vanilin $6 \%$ digunakan untuk visualisasi senyawa yang mengandung gugus aldehid dan keton. Budimarwanti (2007), menyebutkan bahwa vanilin mengandung senyawa aldehid, dimana gugus aldehid yang bereaksi dengan senyawa yang mengandung gugus aldehid juga, akan membentuk suatu spot atau warna tertentu. Alen et al. (2017) menjelaskan bahwa vanilin mampu mendeteksi kandungan senyawa terpenoid, steroid dan komponen minyak atsiri. Pada penelitian ini, setelah sampel disemprotkan vanilin $6 \%$ dan dipanaskan, terjadi perubahan warna dari merah muda sampai ungu kecokelatan pada ke-2 sampel. Hal ini sesuai dengan penelitian Alen et al. (2017), bahwa setelah disemprotkan vanilin 6\% dan dipanaskan, akan terjadi perubahan warna dari merah muda sampai ungu kecokelatan. Berdasarkan penjelasan tersebut, dugaan senyawa yang terdeteksi pada keseluruhan ekstrak Sargassum sp. adalah golongan senyawa fenolat dan terpenoid.

Golongan senyawa tersebut yang membuat ekstrak Sargassum sp. mampu membunuh larva A. aegypti. Ervina et al. (2014), menjelaskan bahwa enyawa fenolat seperti flavonoid merupakan senyawa pertahanan yang bersifat toksik. Flavonoid bekerja sebagai racun pada sistem pernapasan. Senyawa ini masuk ke dalam tubuh larva melalui sistem pernapasan (siphon), sehingga menyebabkan kerusakan dan mengakibatkan larva tidak bisa bernapas hingga akhirnya mati. Sementara senyawa saponin yang termasuk golongan terpenoid dapat masuk ke tubuh larva melalui mulut larva (termakan larva), sehingga aktivitas enzim protease dan penyerapan makanan menurun. Hal tersebut dapat menyebabkan energi untuk pertumbuhan larva menjadi berkurang, lalu terhambat dan akhirnya mati. dapat mengikat sterol bebas dalam pencernaan makanan, di mana sterol berperan sebagai prekusor hormon ekdison. Sehingga dengan menurunya jumlah sterol bebas akan mengganggu proses pergantian kulit pada serangga (Widawati dan Heni, 2013). Kerusakan tersebut terjadi pada larva yang digunakan dalam penelitian ini dan ditampilkan pada Gambar 3.

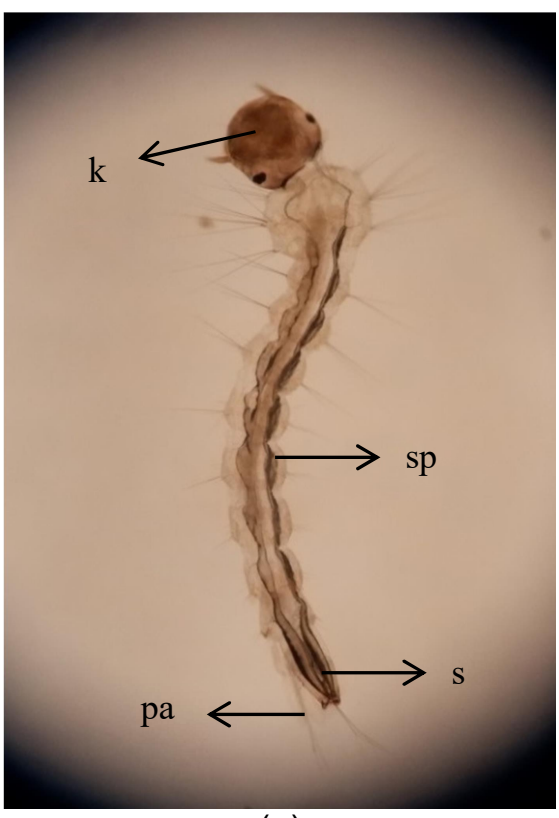

(a)

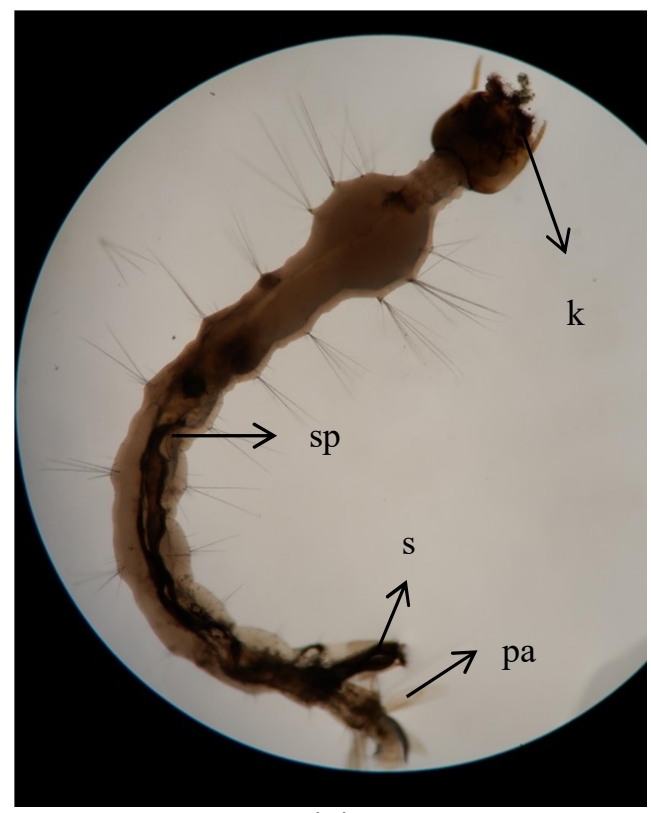

(b)

Gambar 3. Hasil Pengamatan Morfologi Larva A. aegypti. (a) Larva Sebelum Diberi Fraksi Etil Asetat Sargassum sp.; (b) Larva Setelah Diberi Fraksi Etil Asetat Sargassum sp. 
Berdasarkan hasil pengamatan diatas, pemberian fraksi etil asetat Sargassum sp. pada larva A. aegypti menyebabkan adanya perubahan morfologi. Perbedaan yang terjadi antara sebelum dan setelah pemberian fraksi etil asetat adalah kondisi tubuh yang lebih panjang dari sebelum pemberian fraksi etil asetat, warna tubuh yang semula transparan menjadi lebih gelap. Selain itu juga adanya kerusakan di bagian ujung kepala $(\mathrm{k})$ menjadi tidak utuh, perubahan pada ujung siphon (s) yang sebelum diberi perlakuan berbentuk runcing namun setelah diberi perlakuan menjadi berbentuk tabung. Bentuk saluran pencernaan (sp) juga rusak dan semakin menyempit, serta bentuk papila anal (pa) menjadi lebih lebar setelah diberi fraksi etil asetat (Gambar 3). Hasil pengamatan ini sesuai dengan penelitian yang dilakukan oleh Yu et al. (2015). Adanya perubahan morfologi ini diduga karena efek dari senyawa aktif/metabolit sekunder golongan senyawa fenolat dan terpenoid yang ada dalam ekstrak Sargassum sp..

\section{KESIMPULAN}

Berdasarkan hasil penelitian, dapat disimpulkan bahwa ekstrak etil asetat Sargassum sp. memiliki kemampuan toksisitas terhadap larva $A$. aegypti instar III dengan nilai LC $50^{-72}$ sebesar 996,28 ppm. Namun dari hasil tersebut perlu dilakukan uji lebih lanjut agar potensi Sargassum sp. sebagai larvasida dapat dimaksimalkan.

\section{DAFTAR PUSTAKA}

Adinata, I.P.K., Anam, K. \& Kusrini, D. 2013. Identifikasi Senyawa Metabolit Sekunder Fraksi Aktif Daun Jarak Pagar (Jatropha curcas L.) dan Uji Aktivitas Larvasida terhadap Larva Nyamuk Aedes aegypti. Jurnal Kimia Sains dan Aplikasi, 16(2):42-45.

Agustina, E., Andiarna, F., Lusiana, N., Purnamasari, R. \& Hadi, M.I. 2018. Identifikasi Senyawa Aktif Dari Ekstrak Daun Jambu Air (Syzygium aqueum) dengan Perbandingan Beberapa Pelarut Pada Metode Maserasi. Biotropic, 2(2):108-118.

Alen, Y., Agresa, F.L. \& Yuliandra, Y. 2017. Analisis Kromatografi Lapis Tipis (KLT) dan Aktivitas Antihiperurisemia Ekstrak Rebung Schizostachyum brachycladum Kurz (Kurz) pada Mencit Putih Jantan. Jurnal Sains Farmasi dan Klinis, 3(2):146-152.

Arum, Y.P., Supartono \& Sudarmin. 2012. Isolasi dan Uji Daya Antimikroba Ekstrak Daun Kersen (Muntingia calabura). Jurnal MIPA, 35(2):165-174.

Budimarwanti, C. 2007. Sintesis Senyawa Bibenzil Dari Bahan Awal Vanilin Melalui Reaksi Wittig dan Hidrogenasi Katalitik. Universitas Negeri Yogyakarta, Yogyakarta.

Ervina, N., Pratiwi, L.\& Natalia, D. 2014. Uji Aktivitas Ekstrak Etanol Daun Singkong (Manihot utilissima Pohl) Sebagai Larvasida Aedes aegypti. Jurnal Mahasiswa PSPD FK Universitas Tanjungpura, 1(1):1-12

Fajriaty, I., Hariyanto, Saputra, I.R. \& Silitonga, M.. 2017. Skrining Fitokimia dan Analisis Kromatografi Lapis Tipis dari Ekstrak Etanol Buah Lerak (Sapindus rarak). Jurnal Pendidikan Informasi dan Sains, 6(2):243-256.

Kementerian Kesehatan RI. 2010. Buletin Jendela Epidemiologi. 2:1-45.

Khadijah, K., Jayali, A.M., Umar, S. \& Sasmita, I. 2017. Penentuan Total Fenolik dan Aktivitas Antioksidan Ekstrak Etanolik Daunsamama (Anthocephalus macrophylus) Asal Ternate, Maluku Utara. Jurnal Kimia Mulawarman, 15(1):11-18.

Leksono, W.B., Pramesti, R., Santosa, G.W. \& Setyati, W.A. 2018. Jenis Pelarut Metanol dan NHeksana Terhadap Aktivitas Antioksidan Ekstrak Rumput Laut Gelidium sp. dari Pantai Drini Gunungkidul - Yogyakarta. Jurnal Kelautan Tropis, 21(1):9-16.

Lestari, P.P., Kusrini, D. \& Anam, K. 2014. Anthocyanin Identification of Methanol-HCl Extract Active Fraction in Rosella (Hibiscus sabdariffa L) and Its Potential as Xanthine Oxidase Inhibitor. Jurnal Sains dan Matematika, 22(3):72-78.

Leuwol, C.F., Batu, D.T.F.L. \& Affandi, R.. Uji Toksisitas Akut Insektisida Karbamat Terhadap Ikan Mas, Cyprinus carpio Linnaeus, 1758. Jurnal Iktiologi Indonesia, 18(3):191-198.

Mary, J.S., Vinotha P. \& Pradeep, A.M. 2012. Screening for in vitro Cytotoxic Activity of Seaweed, Sargassum sp. Against Hep-2 and MCF-7 Cancer Cell Lines. Asian Pasific of Cancer Prevention, 13:6073-6076. 
Mukhriani. 2014. Ekstraksi, Pemisahan Senyawa, dan Identifikasi Senyawa Aktif. Jurnal Kesehatan, 7(2):361-367.

Noshirma, M. \& Willa, R.W. 2016. Larvasida Hayati Yang Digunakan Dalam Upaya Pengendalian Vektor Penyakit Demam Berdarah di Indonesia. Sel Jurnal Penelitian Kesehatan, 3(1):31-40.

Rahmayanti, R., Putri, S.K. \& Fajarna, F., 2016. Uji Potensi Kulit Bawang Bombay (Allium cepa) Sebagai Larvasida Terhadap Kematian Larva Nyamuk Aedes aegypti. Jurnal Edukasi dan Sains Biologi, 5(1):18-22.

Rochmat, A., Bahiyah, Z. \& Adiati, M.F. 2016. Pengembangan Biolarvasida Jentik Nyamuk Aedes aegypti Berbahan Aktif Ekstrak Beluntas (Pluchea indica Less.). Reaktor, 16(3):103-108.

Suryani, E. . 2018. Gambaran Kasus Demam Berdarah Dengue di Kota Blitar Tahun 2015-2017. Jurnal Berkala Epidemilogi, 6(3):260-267.

Susanti, A.D., Dwi, A., Gita, G. \& Yosephin, B.G. 2012. Polaritas Pelarut Sebagai Pertimbangan Dalam Pemilihan Pelarut Untuk Ekstraksi Minyak Bekatul dari Bekatul Varietas Ketan (Oriza sativa Glatinosa). Universitas Sebelas Maret, Surakarta.

Susanty \& Bachmid, F. 2016. Perbandingan Metode Ekstraksi Maserasi dan Refluks Terhadap Kadar Fenolik dari Ekstrak Tongkol Jagung (Zea Mays L.). Konversi, 5(2):87-93.

Valentina, J., Poonguzhali, T.V. \& Josmin, L.N.L.L. 2015. Mosquito Larvicidal and Pupicidal Activity of Seaweed Extracts Against Aedes aegypti, Anopheles stephensi and Culex quinquefasciatus. International Journal of Mosquito Research, 2(4):54-59.

Widawati, M. \& Prasetyowati, H. 2013. Efektivitas Ekstrak Buah Beta vulgaris L. (Buah Bit) Dengan Berbagai Fraksi Pelarut Terhadap Mortalitas Larva Aedes aegypti. Aspirator, 5(1):23-39.

Wulandari, L. 2011. Kromatografi Lapis Tipis. Cetakan 1. PT Taman Kampus Presindo, Jember.

Yu, K.X., Wong, C.L., Ahmad, R. \& Jantan, I. 2015. Larvicidal Activity, Inhibition Effect On Development, Histopathological Alteration and Morphological Aberration Induced By Seaweed Extracts In Aedes aegypti (Diptera: Culicidae). Asian Pasific Journal Of Tropical Medicine, 8(2):1006-1012. 